\title{
LEARNING STRATEGY TO DEVELOP CRITICAL THINKING, CREATIVITY, AND PROBLEM-SOLVING SKILLS FOR VOCATIONAL SCHOOL STUDENTS
}

\author{
Muchlas Samani ${ }^{1}$, Sunwinarti ${ }^{2}$, Bima A.W. Putra ${ }^{3}$, Reza Rahmadian ${ }^{4}$, and \\ Juni Noor Rohman ${ }^{5}$ \\ ${ }^{123}$ Postgraduate School, Universitas Negeri Surabaya, Indonesia \\ ${ }^{4}$ Department of Electrical Engineering, Universitas Negeri Surabaya, Indonesia \\ ${ }^{5}$ Wroclaw University of Science and Technology, Polandia \\ E-mail:msamani@unesa.ac.id
}

\begin{abstract}
Critical thinking, creativity, and problem-solving skills are critical for vocational schools graduates to enter the workforce in the industrial era 4.0. This study aims to find a learning strategy that can develop these three skills. The study was carried out at SMK X Mojokerto in the Automotive Technology Program in the academic year of 2017/2018. Data were collected using an observation sheet validated by three experts and tested with inter-rater reliability. The data analysis method is t-test. The results of data analysis showed that the Contextual Project Based Learning (CPjBL) was generally effective to improve critical thinking, creativity, and problem-solving skills. Detailed observation included each of these aspects. The findings showed that the implementation of contextualized learning problems could improve the aspect of originality and problem understanding skills, which was usually difficult to improve. On the other hand, CPjBL was not effective in developing the ability of analysis in critical thinking and look-back in problemsolving skills.
\end{abstract}

Keywords: contextual project-based learning, creativity, critical thinking, problem-solving skills

\section{INTRODUCTION}

The era of industrial revolution 4.0 has started with four main characteristics: cyberphysical systems, internet of things, cloud computing and cognitive computing [1]. The industrial revolution 4.0 occurs due to the rapid development of technology, especially information technology [2]. Changes in the industrial stage have resulted in the change of work patterns due to the use of different technologies [3], [4]. Therefore, vocational school graduates who will work as technicians [5], must be prepared to deal with vehicles with technology that is different from what they learned at schools. Samani et al. [6] found that vehicle repairs are carried out through 4 stages: information gathering, analysis of problems, finding solutions creatively, choosing the appropriate alternative, and implementing vehicle reparation. Critical thinking skills, creativity, and problem-solving skills are needed to implement those four steps. Thus, critical thinking, creativity, and problem-solving skills are very important for vocational school graduates.

At present, learning in Vocational Schools tends to use direct instruction while practicing in workshops using SOP (standard operation procedure) that does not stimulate students to think critically and creatively in finding other alternatives to solve their problems. Therefore a learning model is needed that can stimulate the growth of critical thinking, creativity, and problemsolving skills for students of vocational schools.

Critical thinking is a higher order thinking including in the stage of analysis and 
evaluation in Bloom taxonomy [7]. Karakoc [8] mentions people who think critically do not want to receive information as it is, but ask why that is. $\mathrm{He} / \mathrm{she}$ sees things from various points of view and then compares which are the most rational [9]. Therefore critical thinking requires the ability of deductive and inductive thinking skills [10]. Facione [11] states that critical thinking consists of six aspects; they are interpretation, analysis, evaluation, inference, explanation, and self-regulation. In repairing motorized vehicles, this stage is used to analyze the damage occurred and why it happened.

Lu \& Singh [12] mention that students are critical thinkers when they can think logically and deeply to analyze information obtained, to find solutions to problems faced, and to make sense of their world and how things have become the way they are. Meanwhile, Snyder \& Snyder [13] mentions four barriers to learning critical thinking: lack of training, lack of information, incorrect preconception and limited time. Learning process must avoid these obstacles.

Creativity is one of the essential capabilities in the technological era [14], and it consists of a process (creative thinking) and results (creative products) [15]. Creative thinking occurs when someone uses a method that is different from other people in general and then produces something different. Thus, creative thinking produces creative products. In line with that, Cremin et al. [16] states that creativity is the construction of ideas or products that have useful potential.

Can creativity be taught? Boyd and Goldenberg [17] used a method to teach creativity called Systematic Inventive Thinking (SIT). Creativity is more comfortable to grow when students get the opportunity to solve problems in their way and do not have to follow the ways determined by the teacher [18]. Similarly, Henriksen et al. [14] mention that creativity will grow through learning by doing and learning in action, which according to Liu \& Schoenwetter [19] have four aspects: fluency, flexibility, originality, and elaboration.

Problem solving is a skill to transform the current state into a prospective goal [20]. However, good problem solving is not just finding answers but must apply a thorough analysis of the problems that occurred [21]. Therefore, problem solving requires the ability to think critically to understand the problems that occurred [3]. Such problemsolving skills are essential for automotive technicians in repairing vehicles.

Polya in Saygili [22] mentions problem solving through four steps: understanding the problem, devising and choosing the strategy, solving the problem, and checking the problem (look-back). More than that to do problem solving, self-confidence is needed to take the most appropriate choices [23], while self-confidence will grow if problem solving is successful in similar problems [21]. Thus to foster problem-solving abilities students must learn by doing and have an opportunity to make decisions based on their own beliefs.

A learning strategy that allows students to learn by doing, to find, and to choose problem solving according to their beliefs, especially for students of vocational school automotive skills programs is Contextual Project Based Learning (CPjBL). Contextual means that students' assignments are adjusted to their prior knowledge and daily life. Project work means that the task is following real-world problems [24] and students complete the assignment by doing according to their way of thinking [25]. In line with that, Coco in Menzies et al. [26] mentions that $\mathrm{PjBL}$ is characterized by context-specific learning, involved learners in the learning process. This study is aimed at implementing 
Contextual Project Based Learning to improve critical thinking, creativity, and problem-solving skills of the students.

\section{METHOD}

Learning materials were developed based on 4-D (define, design, develop, and disseminate) model [27] but only until the third stage (develop). The effectiveness of the learning strategy was tested by applying a pretest-posttest control group design. The observation sheet validation included three experts, and its reliability test was inter-rater [28], resulting in $82 \%$ for critical thinking instruments, $78 \%$ for creativity instruments, and $86 \%$ for problem-solving instruments. A t-test was applied to see the differences between the two groups.

This study was conducted at SMK X Mojokerto during four weeks in the odd semester of the school year 2017/2018, with a sample of 28 students in the experimental group and 30 students in the control group. To avoid contamination with past experiences, students of 7 th grade were selected. The topics chosen were Jacking, Lifting, and Blocking which constitutes the first part of Basic Automotive Technology.

In the experimental group, students learned the concepts of engineering mechanics and hydraulic as the foundations of theory followed by practicing through $\mathrm{CPjBL}$ at workshops with equipment for jacking, blocking and lifting. Students were given the task to solve the problem of damage to automotive equipment creatively based on a critical analysis of the working system of the equipment.

As long as students worked on the project, the teacher accompanies and allows them to complete the task following the principles of learning by doing based on their way of thinking [25]. In the control group, students learn by using the same equipment, but by applying direct instruction accompanied by demonstrations.

Before taking part in the learning activities, pretests were conducted to test the similarities between the experimental group and the control group. The t-test for the two groups showed: critical thinking: $t=0.335$ with $\mathrm{p}=0.739$; creativity: $\mathrm{t}=738$ with $\mathrm{p}=$ 0.463 ; problem solving: $\mathrm{t}=0.375$ with $\mathrm{p}=$ 0.709 . Thus, the experimental group and the control group are considered equal.

\section{RESULTS AND DISCUSSION}

Figure 1 shows a comparison of the critical thinking scores between the experimental and the control group, starting from the aspects of interpretation, analysis, inference, evaluation, explanation, and selfregulation. It shows that the experimental group was superior to the control group. Assuming that each aspect has the same weight, the mean score of the experimental group is 74.93 while the control group is 58.33 .

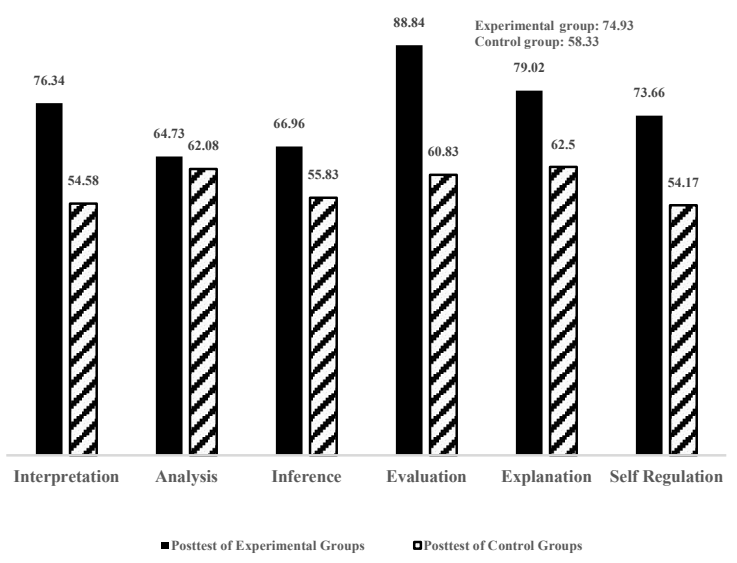

Figure 1. Posttest Score of Critical Thinking

The results of the t-test in Table 1 shows the scores of the experimental group students are significantly higher than the control group students with $\mathrm{p}=0.00$ 
indicating that $\mathrm{CPjBL}$ was effective in developing critical thinking skill.

Table 1. The t-test of Critical Thinking Scores

\begin{tabular}{lcccc}
\hline & \multicolumn{1}{c}{$\begin{array}{l}\text { t-test for } \\
\text { Means }\end{array}$} & Equality of \\
\cline { 3 - 5 } & $\mathrm{t}$ & df & $\begin{array}{l}\text { Sig. (2- } \\
\text { tailed) }\end{array}$ \\
\hline $\begin{array}{l}\text { Posttest on Equal } \\
\text { critical } \\
\text { thinking }\end{array}$ & $\begin{array}{l}\text { variances } \\
\text { assumed }\end{array}$ & 8.945 & 56 & .000 \\
\cline { 2 - 5 } & $\begin{array}{l}\text { Equal } \\
\text { variances } \\
\text { assumed }\end{array}$ & not8.954 & 55.902 & .000 \\
\hline
\end{tabular}

However, the data in Figure 1 shows that students' ability in analysis aspect was still weak with a score of 64.73 for experiential groups and 62.08 for control groups. The t-test between the two groups was also not significant with $t=0.828$ and $p$ $=0.411$. Thus, the CPjBL in Mojokerto $\mathrm{X}$ Vocational School was not effective to improve analytical skill. Analytical skill requires abstract thinking skills [28], while generally vocational students are not very intelligent young people [29], so they do not have high abstract reasoning. Therefore, it is suspected that $\mathrm{CPjBL}$ was not effective for improving students' analytical skills with low abstract reasoning. High scores (73.66) for self-regulation in the experimental group are interesting to study further because usually students at the high school level are not used to evaluating what has been done.

Figure 2 shows a comparison of creativity scores between the experimental group and control group, from the aspects of fluency, flexibility, originality, and elaboration. In all aspects, students in the experimental group with an average of 78.13 was higher than the control group with an average of 67.40 . The results of the t-test between the two groups in Table 2 shows a significant difference with $p=0.00$, so it is concluded that $\mathrm{CPjBL}$ was effective in developing creativity.

However, data in Figure 2 shows a high score on the aspect of originality (79.02). It is different from the usual where the originality score is always the lowest because students are trapped with the theory that is read and/or explained by the teacher [16]. Giving freedom to students to work on their projects according to their own way of thinking turned out to be able to improve the aspect of originality on creativity. This phenomenon is in line with the findings of Boyd \& Goldenberg [17]].

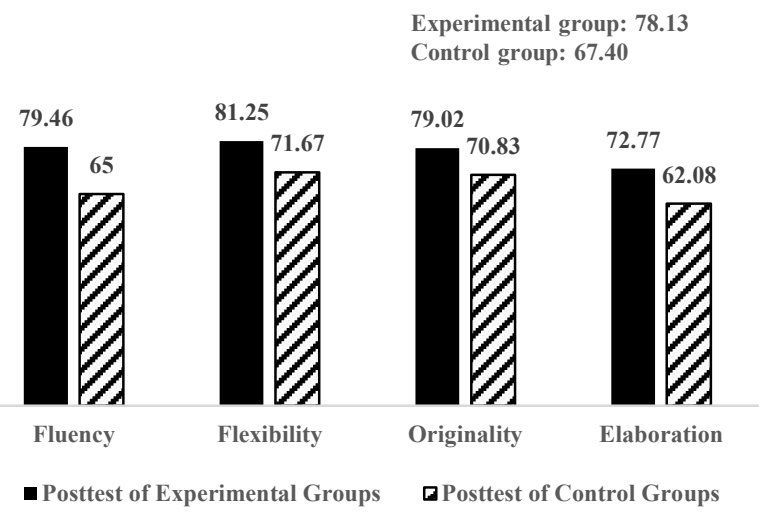

Figure 2. Posttest Score of Creativity

Table 2. T-test of Creativity Scores

\begin{tabular}{ccccc}
\hline & & \multicolumn{3}{c}{ t-test for Equality of Means } \\
\cline { 3 - 5 } & $\mathrm{t}$ & $\mathrm{df}$ & $\begin{array}{c}\text { Sig. (2- } \\
\text { tailed) }\end{array}$ \\
\hline $\begin{array}{c}\text { Posttest } \\
\text { on } \\
\text { creative } \\
\text { thinking }\end{array}$ & $\begin{array}{c}\text { Equal } \\
\text { variances } \\
\text { assumed }\end{array}$ & 8.664 & 56 & .000 \\
& $\begin{array}{c}\text { Equal } \\
\text { variances not } \\
\text { assumed }\end{array}$ & 8.670 & 55.870 & .000 \\
\hline
\end{tabular}

Figure 3 presents a comparison of problem-solving scores between the experimental and control groups from aspects of understanding the problems, devising a plan, carrying out the plan, and looking back. In all aspects, students in the experimental 
group with an average of 77.12 were higher than the control group with an average of 71.77. The results of the t-test between the two groups in Table 3 shows a significant difference with $\mathrm{p}=0.00$; therefore, $\mathrm{CPjBL}$ was effective in developing problem-solving skill.

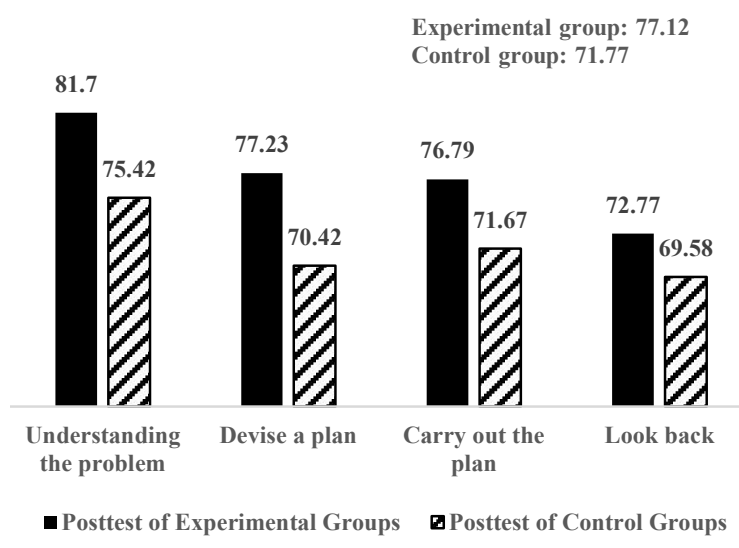

Figure 3. Posttest Score of Problem Solving

Table 3. T-test of Problem Solving Scores

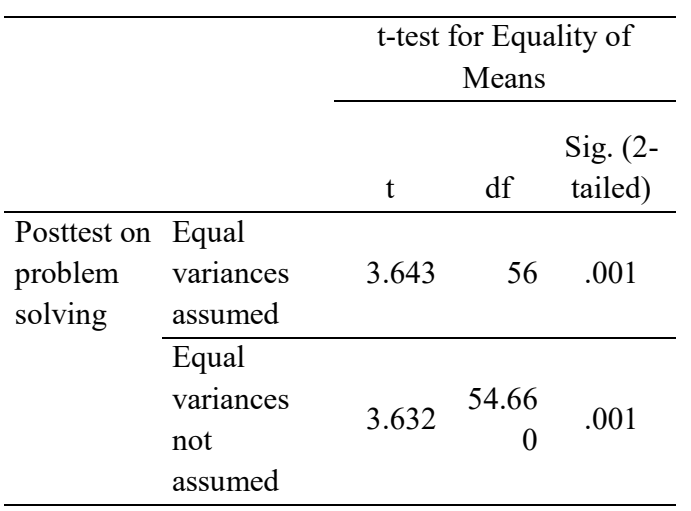

However, there are two interesting data in Figure 3 for further research. First, students in the experimental and the control group had a high score in understanding the problem given. Various studies show that this aspect is usually the most difficult aspect to develop [22]. This phenomenon is most likely caused by the fact that the topics of the project being carried out were jacking, blocking, and lifting, which the underlying theory had been obtained in science subjects at junior high school.
Second, the lowest score is at the lookback skill, and the result of the t-test between the experimental and the control group was not significantly different with $\mathrm{t}=0.941$ and $\mathrm{p}=0.351$. Thus, it is concluded that even though CPjBL was effective for improving problem-solving skills, it was not effective in improving the look back skill. This phenomenon is in line with the results of the research by Samani et al. [6] that students are not accustomed to evaluating what has been done, as Boyd \& Goldenberg [17] say that checking and rechecking is an important job but often forgotten.

\section{CONCLUSION}

Based on the data analysis described above, it can be concluded that in general, the CPjBL was effective to improve critical thinking, creativity, and problem-solving skills for vocational schools students, especially students in Automotive Department. Furthermore, when observed in more detail in each aspect, it was found that the application of contextualized learning problems could improve the aspect of originality in creativity and problem understanding in problem-solving skills, which was usually difficult to improve. However, it should be noted that CPjBL was not effective to improve the capabilities of analysis in critical thinking and look-back in problem solving. In addition, this study used a minimal sample. Therefore, further research is needed to refine the learning materials so that it can improve the analytical and look-back skills followed by a test with a larger sample.

\section{REFERENCES}

[1] C. Klingenberg, "Industry 4.0: What Makes it Revolution," in EurOMA 
2017, 2017.

[2] B. Lavanya, B. S. Shylaja, and M. S. Santhosh, "Industry 4.0-The Fourth Industrial Revolution. Internationa," J. Sci. Eng. Technol. Res., vol. 6, no. 6, pp. 1004-1007, 2017.

[3] M. Samani, "Rethinking Education for 21st Century," in ASAIHL International Conference 2014, 2014.

[4] World Economic Forum, "The Future of Jobs: Employment, Skills and Workforce Strategy for the Fourth Industrial Revolution," Switzerland, 2016.

[5] Ministry of Manpower of the Republic of Indonesia, Surat Keputusan Menteri Tenaga Kerja Republik Indonesia No.113, Tahun 2016, Tentang Penetapan Standar Kompetensi Kerja Nasional Indonesia Kategori Industri Pengolahan Golongan Pokok, Industri Mesin dan Perlengkapan yang Tidak Dapat di Klasifikasikan di Te. 2016.

[6] M. Samani, E. Ismayati, M. Cholik, and Suparji, "Teaching-Learning Strategy for Developing Critical Thinking and Creativity for Engineering Student Teachers," in Crossing Boundaries in Vocational Education and Training: Innovative Concepts for the 21st Century, Michael Ge., Bremen: Institute Technology and Education, Bremen University, 2015, pp. 71-76.

[7] L. O. Wilson, "Anderson and Krathwohl Bloom's Taxonomy Revised," 2016.

[8] M. Karakoc, "The Significance of Critical Thinking Ability in terms of Education," Int. J. Humanit. Soc. Sci., vol. 6, no. 7, pp. 81-84, 2016.

[9] L. M. Murawski, "Critical Thinking in the Classroom and Beyond," $J$. Learn. High. Educ., vol. 10, no. 1, pp. 25-30, 2014.

[10] E. R. Lai, "Critical Thinking: A Literature Review," 2011.

[11] P. A. Facione, "Critical Thinking: What It is and Why It Counts," 2013.
[12] S. Lu and M. Singh, "Debating the Capabilities of 'Chinese Students' for Thinking Critically in Anglophone Universities," Educ. Sci., vol. 17, no. 22, pp. 101-116, 2016.

[13] L. G. Synder and M. J. Snyder, "Teaching Critical Thinking and Problem Solving Skills," Delta Pi Epsil. J., vol. L, no. 2, pp. 90-99, 1008.

[14] D. Henriksen, P. Mishra, and P. Fisser, "Infusing Creativity and Technology in 21st Century Education: A Systemic View for Change," Educ. Technol. Soc., vol. 19, no. 3, pp. 27-37, 2016.

[15] A. J. Cropley, "Definitions of Creativity," in Encyclopedia of Creativity, M. A. Runco and S. R. Pritzker, Eds. San Diego: CA: Academic Press, 2011, pp. 511-524.

[16] T. Cremin, A. Craft, and J. Clack, "Creative Little Scientists: Enabling Creativity through Science and Mathematics in Preschool and First Years of Primary Education," 2012.

[17] D. Boyd and J. Goldenberg, Inside the Box: Why the Best Business Innovation are in Front of You. London: Profile Book Ltd, 2013.

[18] L. S. Tan, S. S. Le, L. D. Ponnusamy, E. R. Koh, and K. C. K. Tan, "Fostering Creativity in the Classroom for High Ability Students: Context Does Matter," Educ. Sci., vol. 6, no. 36, pp. 111-126, 2016.

[19] Z. Liu and D. J. Schoenwette, "Teaching Creativity In Engineering," Int. J. Eng. Educ., vol. 20, no. 5, pp. 801-808, 2004.

[20] C. J. MacLelland, P. Langley, and C. Walker, "A Generative Theory of Problem Solving," in First Annual Conference on Advance in Cognitive Systems: Poster Collection, 2012, pp. $1-18$.

[21] T. Ozturk and B. Guven, "Evaluating Students' Beliefs in Problem Solving Process: A Case Study," Eurasia J. Math. Sci. Technol. Educ., vol. 12, no. 
2, pp. 411-429, 2016.

[22] S. Saygili, "Examining The Problem Solving Skills and The Strategies Used by High School Students in Solving Non-routine Problem," $E$ International J. Educ. Res., vol. 8, no. 2, pp. 91-114, 2017.

[23] S. Wismath, D. Orr, and M. Zhong, "Student Perception of Problem Solving Skills," Transform. Dialogues Teach. Learn. J., vol. 7, no. 3, pp. 1-17, 2014.

[24] N. Halmer, "Project-Based Learning Literature Review," Plymouth, 2014.

[25] S. Bell, Project-Based Learning for the 21st Century: Skills for the Future. Routledge: Taylor and Francis Group, 2010.
[26] V. Menzies, C. Hewitt, D. Kokotsaki, C. Collyer, and A. Wiggins, "Project Based Learning: Evaluation Report and Executive Summary," Durham, 2016.

[27] S. Thiagarajan, D. S. Semmel, and M. I. Semmel, "Instructional Development for Training Teacher," Bloomington Indiana, 2007.

[28] S. Bakir and O. Bicer, "Logical Thinking and Cognitive Development Levels of Pre-service Science Teachers," J. Educ. Res., vol. 5, no. 1, pp. 149-165, 2015.

[29] D. Newhouse and D. Suryadarma, "The Value of Vocational Education High School Type and Labor Market Outcomes in Indonesia, Policy Research,"Washington DC, 2009. 